\title{
風上建物の影響を受ける高層建築物の変動風圧に関する LES
}

一建築物の耐風設計のための非構造格子系 LES の構築(その 2) -

\section{LES OF FLUCTUATING WIND PRESSURES ON A HIGH-RISE BUILDING INFLUENCED BY WINDWARD BUILDING}

- Formulation of LES using unstructured grid system for wind-resistant design of buildings (Part 2) -

\author{
吉川＼cjkstart優*，田村哲 郎** \\ Masaru YOSHIKAWA and Tetsuro TAMURA
}

\begin{abstract}
Large Eddy Simulation (LES) is expected to be adopted as an effective technique to evaluate wind load on buildings for wind-resistant design. For numerical prediction of wind pressures by LES, unstructured grid system is effective in terms of flexibility in generating computed models. In this paper, the fluctuating wind pressures on a high-rise building influenced by windward building are examined using unstructured LES. Especially, focusing on the critical phenomena regarding pressure intensification, the availability of LES is examined by comparison with experiments and the flow fields are studied to elucidate the mechanism of peak pressure occurrence.
\end{abstract}

Keywords : Wind pressure, High-rise building, LES, CFD, Unstructured grid system, Wind tunnel test 風圧力，高層建築物，LES，CFD，非構造格子，風洞実験

1. はじめに

近年，都市部を中心として高層建築物が高密度に計画・建設され る事例が増えており，建築物の耐風設計に際して周辺建物の影響を 考慮する重要性が高まっている。高層建築物の設計用風荷重を評価 する上で, 特に風上側に同規模の建築物が存在する場合には, 単独 に建つ場合に比べて空力特性や応答特性が大きく変化することが既 往の研究からも明らかにされており, Bailey ら 1), 谷池ら 2),3)をは じめとして実験的研究に基づく多くの成果が報告されている。近年 においては, 主に外装材の設計用風荷重評価を目的とした実験事例 もみられ, 複雑に分布する局所的な風圧変動特性も示されるように なった。

寺崎・中村 ${ }^{4}$ ) は高層建物のピーク外圧に着目し, 多数の風圧実験 に基づいて風上側建物の影響を明らかにしている。特に, ピーク外 圧の発生位置を明示している点, また風上建物規模や相対角度の影 響について述べている点が特徴であるとともに, 建物壁面の領域ご とに最大值が示されていることから設計資料として有益である。同 文献では, 高層建物上端部において顕著に大きいピーク外圧(負圧) が発生することが明らかにされている。ピーク外圧の増加現象は, 外装材の耐風設計上極めて重要であり, 風荷重評価において適切に 考慮されなければならない。しかしながら, 風洞実験では外圧変動 に関与する流れ場を精度よく計測するのは困難であるために，ピー ク外圧を増加させる流れのメカニズムについては吟味されていない。
一方，今後の耐風設計における風荷重評価技術として数值流体計 算（CFD）の適用が期待されている。建築物に作用する変動風圧を CFD で得るためには, 直接非定常解を得られる点で LES (Large Eddy Simulation）が有効であり, 近年では複雑モデルを対象とし た計算事例も報告されるようになってきた。周辺建物の影響を扱っ た計算事例では，小野ら5)䓅接する 2 棟の実建物形状を対象とし て構造格子（重合格子）を用いた計算結果を報告しており，空気力 係数について良好な計算精度が確認されている。しかしながら，一 般座標系の制約に伴って特殊な境界処理が施されており, 計算モデ ル構築法としては汎用的でない。また, Tamura・Nozu・Kishida ら 6) 9)は実市街地を対象とした LES を実施し, 周囲の建物群によ る乱流構造の変化や隣接建物による風圧分布の影響について報告し ている。計算モデルに関して, 従来の構造格子系から非構造格子と のハイブリッドモデルに至る一連の工夫によって予測精度が改善さ れているが，格子の質に起因してピーク外圧評価に課題を残してい る。

以上より，周辺建物の影響を受ける高層建築物を対象とした LES においては, 計算モデルを適切に構築することが重要となる。すな わち, 複数の建物モデルに対する形状再現性を確保しつつ, 各建物 周囲で発生する複雑な乱流場を十分に解像できるような適切な格子 配置が求められる。

著者らは前報 10)において, 3 次元角柱に作用する変動風圧を LES
* 大成建設侏技術センター 主任研究員・修士 (工学)

** 東京工業大学大学院総合理工学研究科 環境理工学創造専攻 教授・工博
Senior Research Engineer, Technology Center, Taisei Corp., M. Eng.

Prof., Dept. of Environmental Science and Technology, Tokyo Institute of Technology, Dr. Eng. 
で求め, 複数の実験值との比較に基づきその計算精度を検証すると ともに非構造格子の有効性を示した。ここで使用されたテトラ要素 による非構造格子系は, モデル構築における自由度の高さ故に上記 の課題を解決でき, 複雑モデルに対しても効果的に精度のよい解を 得られると考えられる。

本研究では, 風上建物の影響を受ける高層建物の変動風圧を対象 として, 非構造格子系 LES を実施する。特に実務的な観点から, モデルの複雑さに起因して設計用風圧力が増加するケースを重要と 捉え, ピーク外压が顕著に増加する事象を対象として本計算法の妥 当性を吟味する。まず, 適切な計算モデル構築を目的とし, 建物間 の格子解像度に着目してその影響を調べる。次に, 風上建物によっ て顕著にピーク外圧が増加する事例 2 ケースを対象として非構造格 子系 LES を実施し, 実験值との比較により計算精度を検証する。 さらに計算結果を用いて流れの可視化を行い, ピーク外圧の増加メ カニズムを流れ場に関連づけて考察する。最後に, 建物形状による ピーク外圧の低減効果について検討する。

\section{2. 風洞実験におけるピーク外圧の増加事例}

\section{1 建物モデル}

本研究対象の高層建物モデルは, 幅 $(B)$ ：奥行 $(D)$ : 高さ $(H)=1$ :

1：4の 3 次元角柱 2 棟とする。風上側建物を隣接建物とし, 変動 風圧を求める対象建物は風下側建物と寸る。風下側建物の建物寸法 は $B=D=50 \mathrm{~m}, H=200 \mathrm{~m}$ を想定し, 頂部設計風速は $U_{\mathrm{H}}=49.1 \mathrm{~m} / \mathrm{s}$ と した。風上側建物については, 風下側建物と同規模の場合および $1.5 B \times 1.5 D \times 1.5 H$ の場合の計 2 ケースとした。

\section{2 風洞実験概要}

本研究で行う非構造格子系 LES の精度検証を目的として，寺崎 ら 4)による風洞実験を参照する。本実験は，上記の高層建物モデル に関して模型縮尺率 $1 / 500$ とした多点風圧実験である。実験写真を Fig. 1 に, 風圧測定点配置を Fig. 2 に示寸。実験気流は地表面粗度 区分III とし，実験風速は $11.5 \mathrm{~m} / \mathrm{s}$ である。実験では, 対象建物の風 上側に隣接建物モデルが一棟配置され, 建物寸法, 建物間距離, 実 験風向等をパラメータとして対象建物壁面における変動風圧 $(476$ 点）が計測された。計測された変動風圧力は, 代表高さ $H$ における 基準速度圧を用いて風圧係数に変換され，実大 1 秒相当の移動平均 化処理が施された上で実大 10 分間波形ごとの風圧係数に対して 6 回のアンサンブル平均によって各種風圧係数が求められている。

実験結果より，Fig. 3 に示寸 2 ケースにおいて対象建物の側面端 部 (最上測定層) で非常に強い負圧側ピーク外圧係数の発生が確認 された。一方は, 風上側建物が対象建物々同規模で建物間距離 $(\Delta x, \Delta y)=(2 B, 2 B)$ の条件であり, これをケース $\mathrm{A}$ とする。他方は, 風 上側建物が対象建物の 1.5 倍の寸法を有し, 建物間距離 $(\Delta x, \Delta y)=(1.5 B, 3 B)$ の条件であり, これをケース $\mathrm{B}$ とする。両ケース ともに, 風向角は壁面正対方向から $25^{\circ}$ であり, 負圧側ピーク外圧 係数として-4.2 超える。これは, 同建物モデル単体時における実 験結果の約 1.6 倍に相当するとともに, 設計值として各種規基準に 示されている值（-3.0）よりも大きいことから，耐風設計上考慮す べき現象である。本研究では, これらのケースを対象として非構造 格子系 LES の再現性を検証する。

\section{3. 解析手法}

\section{1 乱流解析手法}

支配方程式は非圧縮性の Navier Stokes 方程式および連続の式で ある。

$$
\begin{aligned}
& \nabla \cdot \mathbf{u}=0 \\
& \frac{\partial \boldsymbol{u}}{\partial t}+(\boldsymbol{u} \cdot \nabla) \boldsymbol{u}-\frac{1}{R e} \nabla^{2} \boldsymbol{u}+\nabla p=0
\end{aligned}
$$

乱流モデルは LES とし, SGS モデルは Smagorinsky モデルを採 用する (Smagorinsky 定数 $C \mathrm{~s}=0.15$ )。離散化手法は FVM（有限 体積法）であり，流速および圧力の各物理量は格子節点に配置され る。空間の離散化精度は 2 次精度中心差分, 時間項については 2 次 精度陰解法とする。解析法の詳細については文献 10)を参照されたい。

\section{2 計算格子の概要}

前報同様, 非構造格子系を採用する。非構造格子系は, 要素形状・ 要素配列ともに制約がないことから，モデル形状や格子解像度に対 して高い自由度を有する。複雑モデルにおいても物体表面形状を完 全に保持でき，かつ計算空間内の格子の粗密を自由に調整できるこ とから多様な流れ場に適応可能であるため，将来的に高い実用性を 期待できる。本研究では, 主にテトラ要素で構成された非構造格子 系を使用する。計算領域内のテトラ要素はアドバンシングフロント 法に基づいて自動生成され，固体境界においては境界層要素（プリ ズム要素）が捜入される。

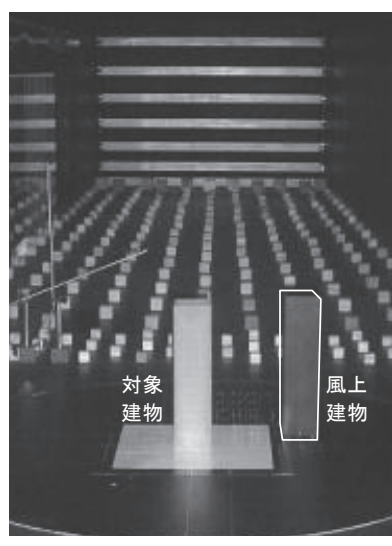

Fig.1 Wind tunnel experiment

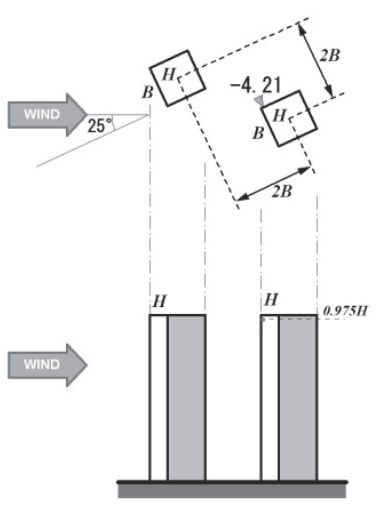

case-A

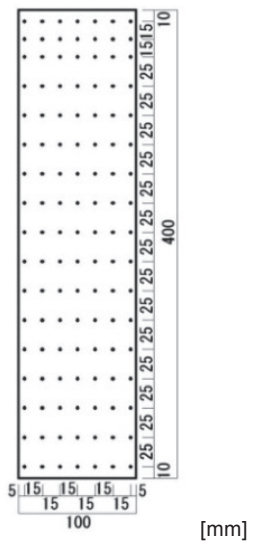

Fig.2 Test model

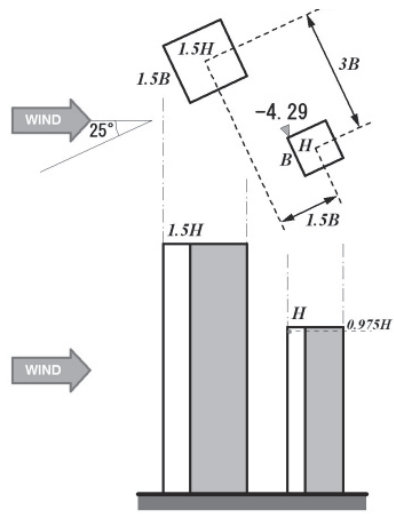

case-B
Fig.3 Experimental conditions of peak occurrence 


\section{3 流入変動風}

建築物の変動風圧評価のための LES において, 流入境界条件とし て要求される流入変動風は, Fig. 4 に示すモデルを用いて作成した。 本計算は，モデル形状として設置されたスパイヤおよびラフネスブ ロックにより境界層乱流を発達させ, 流出境界近傍の仮想断面にお ける全節点で時刻歴変動風速を保存するものである。本手法により 作成された流入変動風のプロファイル（平均風速および乱れの強さ の高さ方向分布）をFig. 5 に, パワースペクトル密度をFig. 6 に示 す。各図には精度検証用の風洞実験における風洞気流の值も併せて 示す。各図より, 計算および実験の気流条件は概初同一であるとい える。

\section{4. 角柱 2 棟を対象とする非構造格子系 LES}

\section{1 計算領域}

前章に示すケース Aおよびケース B を対象として非構造格子系 LES を実施する。解析領域 (ケースA) をFig. 7 に示す。領域規模 は, 幅 $20 B$, 奥行 $30 B$, 高さ $15 B$ である。流入境界から対象建物ま での距離は $8 B$, 風上建物までの距離は $5.4 B$ である。流入境界面に は，前節に示寸変動流入風を時間刻みごとに与える。建物モデルは 主流方向に対して $25^{\circ}$ の角度を有寸るとともに, 各ケースの実験条 件と一致するよう作成・配置する。

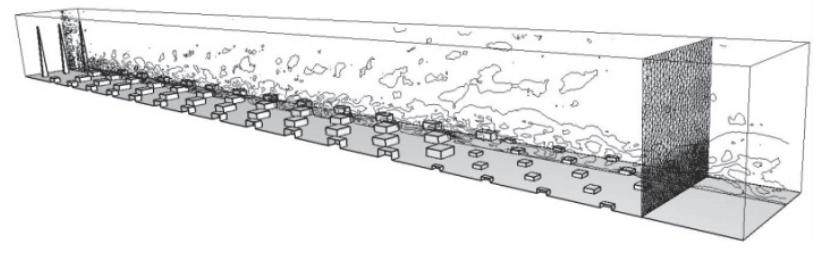

Fig.4 Computed model for inflow turbulence
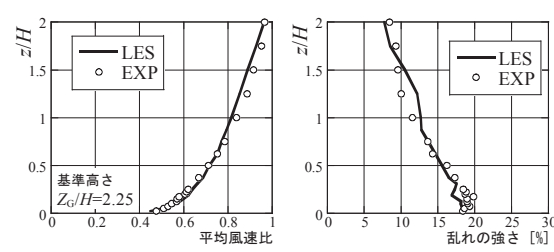

Fig.5 Profiles of wind velocity

Fig.6 Power Spectrum Densities of Wind Velocity

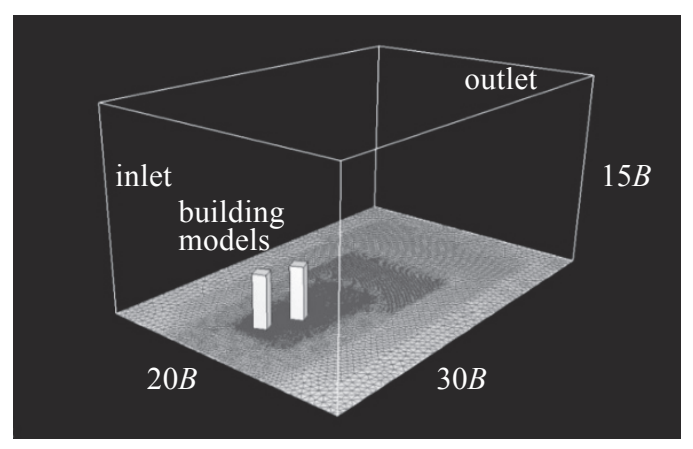

Fig.7 Computed region

\section{2 計算モデルの構築}

計算対象が建物モデル単体の場合, 一般的な計算格子の作成法と して, 遠方から建物表面に向けて格子解像度を上げ，特に剥離点と なる隅角部近傍で高解像度となるよう配慮される。一方，モデルに 周辺建物が存在する場合には, 周辺建物近傍において比較的低い解 像度を割り当てることで計算の効率化が図られることが多い。しか しながら，周辺建物を含むモデルにおける計算格子の影響について は未だ明らかにされておらず, 適切な解を得るための計算モデル構 築法を検討する必要がある。特に本研究対象のように, 風上側に位 置する建物が直接的に対象建物に影響をおよぼすことが想定される 場合には, 建物間の空間における解像度が重要となることが考えら れる。ここではまず, ケース Aを対象として特に建物間の格子解像 度の影響について調べ, 周辺建物の影響を適切に評価するためのモ デル構築法を示す。Fig. 8 は, 建物間において格子解像度の異なる 2 種類の計算モデルを示している。格子の生成手法は前報 ${ }^{10)}$ 同様で あり，各領域ごとに与えられたセルの基準寸法に準じて表面メッシ ユから内部にテトラ要素が自動生成されるものである。両モデルと も, 風下側の対象建物モデル周囲については適切に考慮されており, 前報の角柱（単体）の事例に準拠した解像度で構成されている（隅 角部のテトラ基準寸法 $B / 64$, 壁面上境界層要素はプリズム厚 $B / 250$ $\times 3$ 層)。風上側の建物モデルについては, 風下側の対象建物より若 干解像度が低いものの, その表面上では両モデルで同様の解像度が 与えられている(テトラ基準寸法 $B / 32$ 、境界層要素厚 $B / 167 \times 3$ 層)。 Fig. 8(a)のモデルの位置づけは, 風下側の対象建物にのみ適切な格 子を配置し, 風上側建物はその形状再現のみ考慮した場合に相当す る。一方, Fig. 8 (b) のモデルでは, 風上側建物の周囲においても空 間的に十分な範囲で流孔場を解像するとともに，風下建物隅角部の ピーク外圧発生に関与する流れを考慮し, 建物間の空間における乱 流構造を十分に捉えられるよう格子解像度が確保されている（基準 寸法 $B / 32$ )。両モデルにおいて建物間の空間における格子解像度の 差は, テトラ要素の基準寸法で約 8 倍である。

これらの計算モデルによる計算結果として, Fig. 9 に瞬間渦度の 水平分布を示寸。風下側の対象建物周囲においては同様の格子解像 度であるために概襟しく乱流構造が解像されているが, 一方, 建 物間の空間においては格子解像度による差が顕著に現れており, 風 上側建物からの剥離せん断層が風下の対象建物隅角部に作用寸る過 程においてモデル(b)では十分に細かい乱流構造として再現されて いる。Fig. 10 は, 建物間の中点における変動風速の各 $u, v$ 成分 (Fig. 8 (a)参照) のパワースペクトルを比較したものである。当該 領域において低解像度のモデル (a) は、格子幅に基づくフィルタリン グ効果により高周波数域において大きく減衰し, 特に $V$ 成分につい てはエネルギーピークが捉えられていない。Fig. 11 は, 風下側の対 象建物の上端部においてピーク負圧が増加する点の外圧係数に関す るパワースペクトルを実験值と比較したものである。高解像度のモ デル (b) は, 高周波数域に至るまで実験值をよく再現しており, 外圧 変動を決定づける渦構造を精度よく予測していることが確認できる。 当該位置は両モデルともに高解像度領域に含まれているため, モデ ル (a) においても高周波数成分に若干の回復傾向がみられるものの, 実験值との比較から周波数特性の再現性は十分でない。

以上より, 当該モデルに関して適切な計算モデル構築を行うため 
には, 対象建物のみならず周辺建物に起因する流れの影響を考慮し て格子解像度を定める必要がある。特に非構造格子系を用いる場合 は, モデル構築の自由度が高い反面, 物体形状の再現性にのみ着目 すると空間的な格子解像度が不足することが危惧されるため, 再現 す心゙き流れのパターンを十分に考慮して格子を生成するよう配慮が 必要である。

本研究では, ケースAに対してFig. 8(b)に示した計算モデルを採 用寸る。ケースAの格子全体図（水平断面）をFig. 12 に, 対象建物 の表面メッシュ（ケース A・B 共通）をFig. 13 に示す。ケース B の 計算格子については, 上記の知見を踏まえ、風上側建物周囲におい ても空間的に十分な解像度を保持させるとともに, 風上側建物から の剥離せん断層が対象建物隅角部に作用する領域を考慮し, 建物間 で同様の格子解像度とした (Fig. 14)。本モデルの総要素数は, ケー スAで約 740 万, ケースB で約 810 万である。

\section{3 計算結果}

前節に示した計算モデルによる非構造格子系 LES の結果につい て風洞実験結果との比較を行う。計算結果の処理については風洞実 験と同様とし, 变動風圧波形に対して実大 1 秒相当の移動平均を施 し, 実大 10 分間相当の波形ごとに各種外圧係数を求めてアンサン ブル平均を行った。アンサンブル平均回数は，実験・計算ともに 6

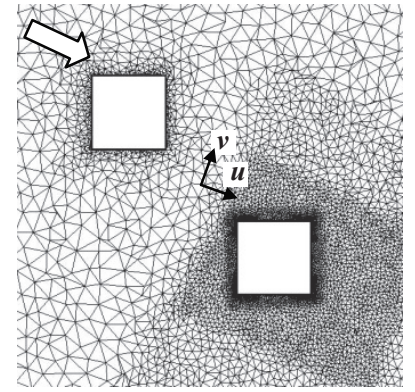

(a)建物間低解像度

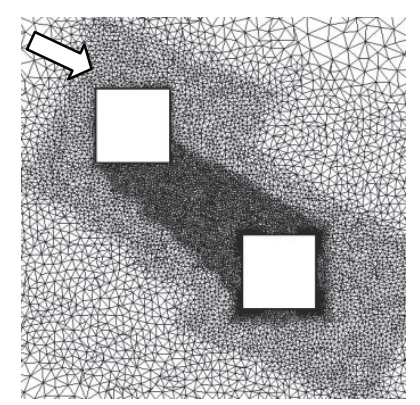

(b)建物間高解像度

Fig.8 Computed models

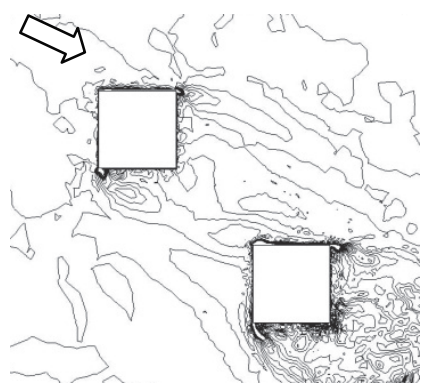

(a)建物間低解像度

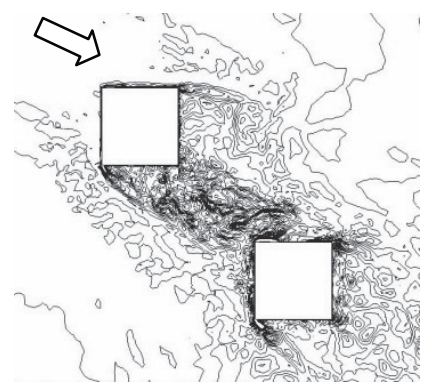

(b) 建物間高解像度

Fig.9 Instantaneous vorticity distributions

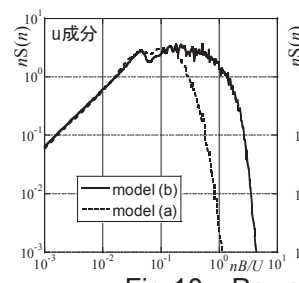

Fig.10 Power spectrum of velocity fluctuation

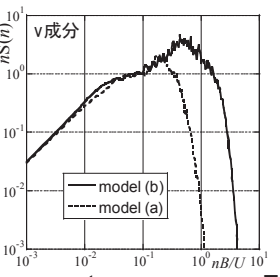

Fig.11 Power spectrum of pressure coefficient

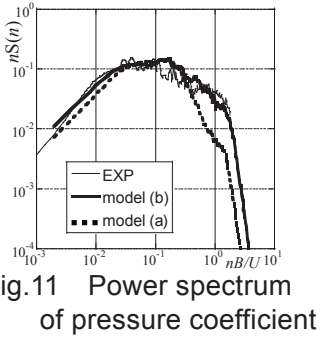

回である。ここで, 計算結果から外圧係数を算定する際の速度圧は, 流入変動風の対象建物代表高さ $H$ における平均風速から求めた。 Fig. 15 は, 対象建物側面において非常に強いピーク負圧が発生した 測定高さ $(0.975 H)$ および中間高さ近傍 $(0.525 H)$ の水平断面に おける平均外圧係数およびピーク外圧係数（正側および負側）の分 布を示している。実験值と計算值を比較すると, まず強い負圧側ピ 一ク外圧係数が計測された点 $(z=0.975 H, x / B=4$ 付近)については, ケース A で実験值- 4.21 に対して計算值-4.21, ケース B で実験值 -4.29 に対して計算值- 4.42 であり，本研究で着目している局所的な 圧力現象が良好な精度で再現されている。一方，他の領域における 外圧分布については，定性的にみれば実験值と計算值で概ね同様の 分布形状となっているものの, 定量的には最大で約 $40 \%$ 程度ピーク 外圧係数に差がみられ，各種条件が同様でありながら前報の単体角 柱の事例と比較してその差が若干大きい。前報においては複数の実 験值との比較に基づき計測・評価上のばらつきや接近流特性の影響 について述べたが，本モデルにおいては対象建物に対する接近流自 体に風上建物の影響が含まれるために，現象のばらつきや計測・評 価誤差が蓄積されていることが要因として考えられる。Fig. 16 は, 風向 $25^{\circ}$ におけるケース $\mathrm{A}$ と単独角柱（風下建物のみ）の実験值に ついて, 各 10 分波形におけるピーク外圧係数のばらつきを示した ものである。風上建物の影響を受けるケース $\mathrm{A}$ では，特に絶対值の 大きい領域（風上面の正圧側ピーク值，側面・背面の負圧側ピーク 值）でそのばらつき幅が単独角柱よりも大きく，対象建物まわりの 圧力場の非定常性が強められていることが想定される。さらに，ば らつき幅の大きい数箇所について 10 分間ピーク值の時刻歴を Fig. 17 に示す。同図より, 単独角柱に比べて本モデルでは実験・計 算ともにばらつき幅が大きいことがわかる。計算值のばらつき傾向 については，まず強いピーク負圧の点（ $x / B=3.95 ）$ ではばらつき幅

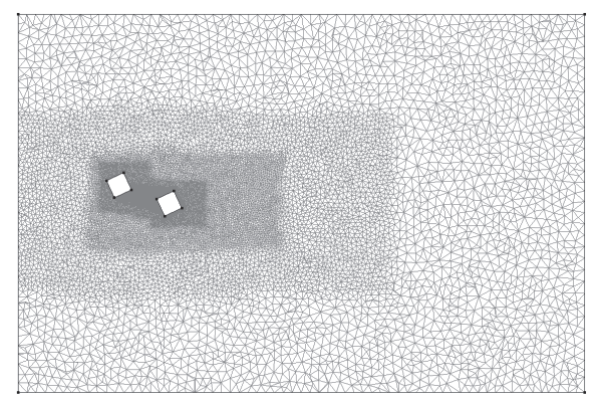

Fig.12 Unstructured grid system for case-A

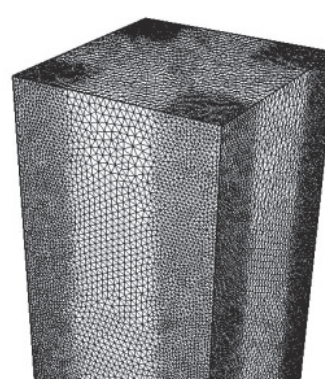

Fig.13 Surface mesh

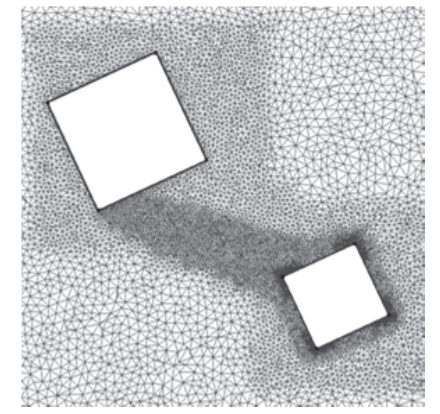

Fig.14 Grid system for case-B 
が実験值とほぼ一致しており, 個々のピーク現象も良好に予測され ていることが確認できる。他の部位では, 実験值のばらつき幅に対 し計算值の多くがその近傍に分布するためピーク現象は概初再現さ れていると推測されるものの, 部位により顕著に絶対值が大きいピ 一ク值の発生が確認される場合がある。これは結果的にアンサンブ ル平均值 (Fig. 15) を絶対值で大きく評価する要因となっているが, 現象としての発生可能性については今後の課題としたい。
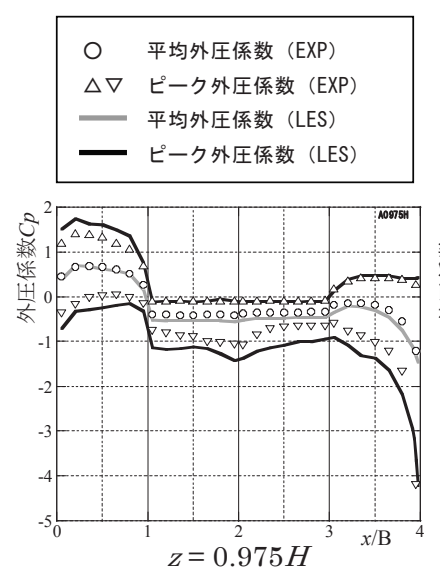

(1) ケース

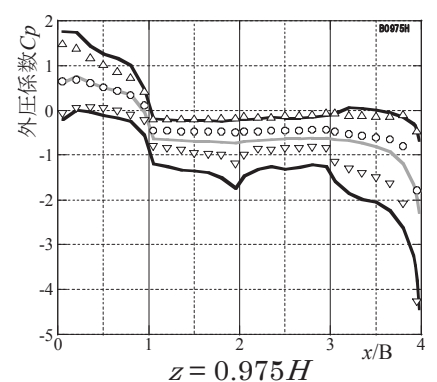

(2) ケース B

Fig.15 Horizontal distributions of pressure coefficients

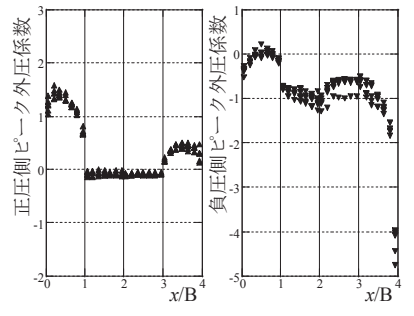

(1)ケースA

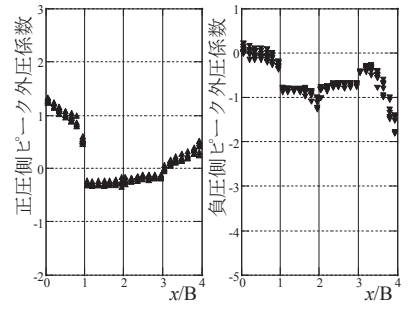

(2)単独角柱
Fig.16 Dispersion of peak pressure coefficients for experiments

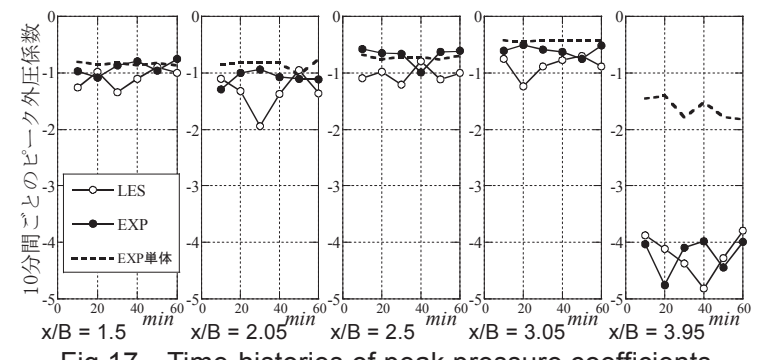

Fig.17 Time-histories of peak pressure coefficients
Fig. 18 は, ケースAにおいて強いピーク負圧の発生点を含む側面 を対象とした各外圧係数の面分布であり，実験值と計算值を併せて 示している。同図より, 当該壁面の各外圧係数について, 実験值と 計算值は同様の分布傾向を示していることがわかる。分布特性とし ては，平均外圧係数・変動外圧係数ともに隅角部の限られた領域で 負圧が強められていること，また本研究で着目しているピーク負圧 の極端な増加現象は上端部のごく僅かな領域でのみ発生しているこ とが確認できる。

以上の検証結果より，本計算結果に基づく外圧分布は、部分的な 実験值との誤差やぼらつきについて一部課題が残るものの，実験值 の傾向を概ね十分な精度で捉えられており，本事象のような特殊な 圧力場に対して本計算法および計算モデルは妥当であると判断され る。

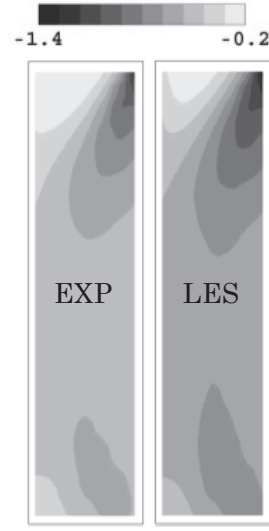

平均外圧係数

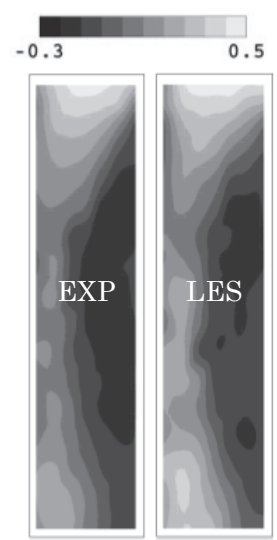

正圧側ピーク外圧係数

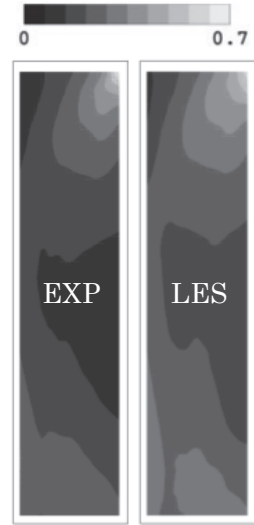

変動外圧係数

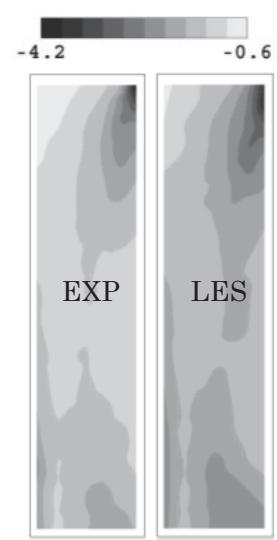

負圧側ピーク外圧係数
Fig.18 Surface distributions of pressure coefficients for case-A

\section{4 ピーク外圧の増加現象に関する考察}

建物表面における外圧分布がその周囲の流れ場から特徵づけられ ることを考慮すると, 本計算結果は対象建物まわりの非定常流れを 十分に再現していると判断される。ここでは，計算結果に基づいて 建物モデル周囲の流れを可視化し，ピーク負圧の増加現象と関連づ けて考察する。

\section{4.1 条件付き平均流れ場}

対象建物の側面上端部におけるピーク負圧の発生現象を調べるこ とを目的として, 条件付き平均流れ場を求める。サンプリング条件 
はケース $\mathrm{A} ・ \mathrm{~B}$ 共通とし, ピーク負圧の発生点における外圧係数の 瞬間值で -4.0 以下とした (Fig. 15 に示した負圧側ピーク外圧係数の 約 $95 \%$ に相当する)。Fig. 19 に, ケースAのピーク負圧発生点にお ける外圧係数の 10 分間波形 (1 サンプル) およびサンプリングレベ ルを示す。同図より, 強いピーク負圧は間欠的に生じていることが わかる。各ケースそれぞれについて, 非定常計算結果の中から条件 に一致する瞬間流れ場の夕抽出し, それらを平均化することで, ピ 一ク負圧の発生現象に関与する流れ場をより明瞭に検証できる。

Fig. 20 およびFig. 21 は, ケースA・Bそれぞれについて条件付 き平均流れ場を可視化したものである。各図において，(a)は最上層 高さ $(0.975 H)$ すなわちピーク負圧発生高さ，(b)は中間高さ近傍 $(0.525 H)$ の水平断面であり、右図は対象建物隅角部の拡大図を示 している。

Fig. 20 (a)より，ケースA $(0.975 H)$ では風上建物隅角部からの 剥離せん断層が対象建物隅角部に向かって伸びており, 対象建物側 面に沿うよう流下寸る流れ場がみられる。この時, 対象建物の隅角 部においてきわめて局所的に剥離・再付着が起こり, 微細な渦構造 が現れている。この領域はピーク負圧発生位置に対応していること から，当該現象に関与する渦構造であると考えられる。

一方, Fig. 20(b) (ケースA, 0.525H) では, 風上建物の後流域に 大きいスケールの渦構造が現れるとともに, 流れが建物間で強く拘 束されているため, 剥離せん断層は大きく蛇行している。対象建物 からの剥離流れは風上建物後流域に強く巻き込まれ, 対象建物側面 の渦構造は壁面から離れた位置に存在している。

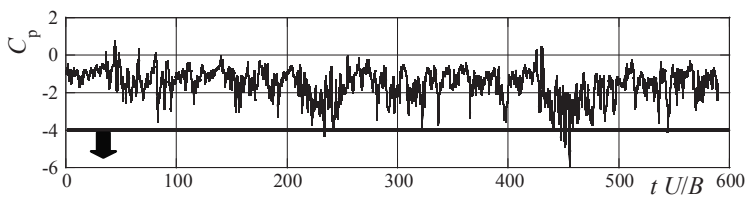

Fig.19 Time-history of $C p$ and sampling level

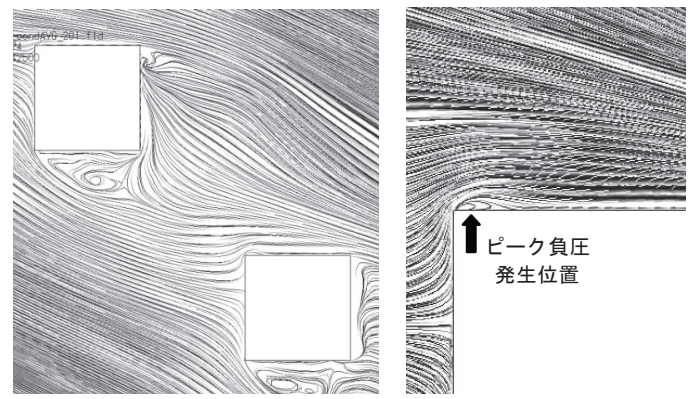

(a) $z=0.975 H$

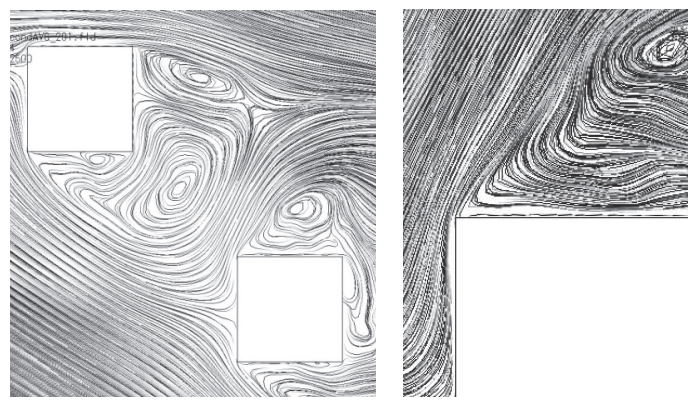

(b) $z=0.525 H$

Fig.20 Conditional averaged flow field for case-A
ケース B （Fig. 21）については，(a)（b)それぞれの高さにおいて 比較的類似した流れ場が形成されている。すなわち、風上建物後流 域には明瞭な渦構造が形成されるとともに，風上建物からの剥離せ 几断層は風下の対象建物側面を沿うよう流れている。対象建物隅角 部では，Fig. 20 (a) と同様に局所的な渦構造が現れるが，Fig. 21 (b) に示される渦構造は, Fig. 21（a)のものよりも再付着点が風下側に 移動していることから引き延ばされた形状として現れている。これ は，風上建物からの剥離せん断層の位置が各高さでわずかに異なっ ているためであると推察される。すなわち, ケース $\mathrm{A} の$ 場合と同様 に，Fig. 21（b)でも流れの拘束による巻き込みが若干生じるが，ケ 一ス B の建物配置はケース $\mathrm{A}$ に比べて, 風向に対して建物間の抵抗 が比較的少ないために強い巻き込みは起こらず，側面において再付 着による渦構造が形成されると考えられる。

\section{4.2 負圧場の空間分布}

前項に示した条件付き平均流れ場の計算結果を用いて, 負圧場の 空間分布を調べる。Fig. 22 は, 対象建物の表面近傍における風圧係 数が-1.0, - 1.5, - 2.0, - 3.0 に相当する圧力等值面を示している。各ケ 一スともに側面上端部を起点とした強い負圧領域が確認され，円錐 渦が形成されていることがわかる（当該領域にはピーク負圧発生位 置が含まれている)。風圧係数 -2.0 以上の等值面においてはケースに よる違いが顕著に現れており，ケース Aでは渦構造が壁面から離れ ているのに対し，ケース Bでは壁面に付着するよう分布している。 これは，前項で流れ場を示したように，建物間における流れの巻き

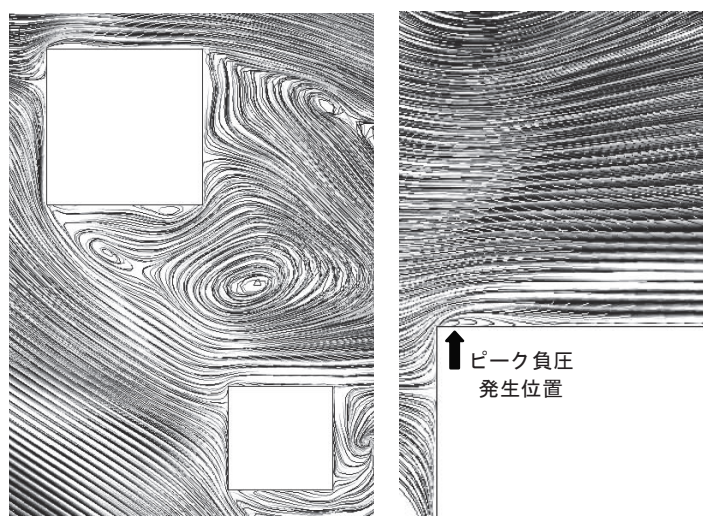

(a) $z=0.975 H$

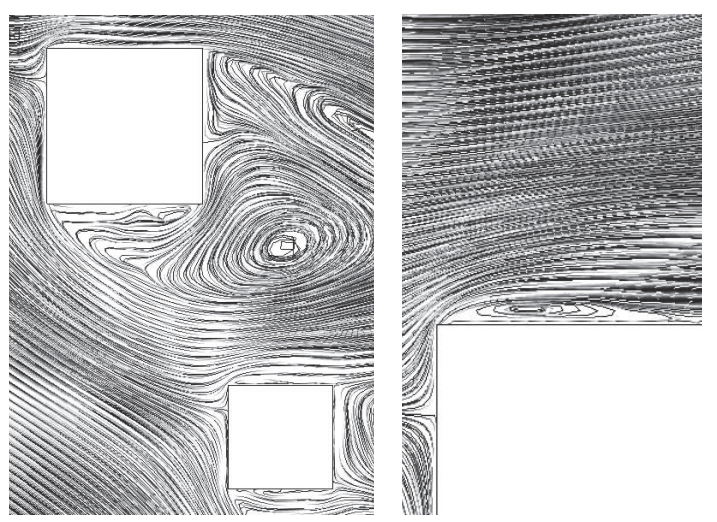

(b) $z=0.525 H$

Fig.21 Conditional averaged flow field for case-B 
込みの強さに起因して, 対象建物からの剥離渦の位置が両ケースで 異なるためである。結果的にケース B では, 比較的強い負圧領域が 下方まで広がるものとなる。これは, 外圧係数の水平分布特性とし て Fig. 15 (2) $(0.525 H ， x / B=4$ 付近）からも確認できる。

3 次元角柱の側面上端部における円錐渦の形成については，既往 の研究においても小野ら 11)が一般座標を用いた LES で明らかにし ている。単独角柱（アスペクト比 4) のピーク負圧を考察するもの であるため本研究対象とモデルは異なるが，条件付き平均流れの計 算に基づきグランシングアングル（風向 $15^{\circ}$ ) で同様の円錐渦構造 が角柱上端部に発生寸ることが示されている。本研究における接近 流の風向角は $25^{\circ}$ であるが, 対象建物に作用寸る風向は風上建物か らの剥離流れの影響を受けていること（Fig. 23 に時間平均流線を示 す), また同文献における円錐渦の発生機構に関して風向変動の関与 が示されていることを考慮すると，本対象建物モデルにおいて形成 される円錐渦は単独角柱で起こる現象と類似している可能性がある。 ここでは，角柱上端部の円錐渦発生に関する現象を比較するため, 単独角柱 (アスペクト比 4) の計算結果についても検証する。Fig. 24 に単独角柱を対象とする計算モデルを示す。接近流は 3.3 に示した 変動流入風を使用し, 風向は $15^{\circ}$ とした。

本モデルを用いて非定常計算を行い，角柱の変動外圧を求めたと ころ，側面上端部に同様のピーク負圧が発生することが確認された (Fig. 25)。ケース A・B と同様の分析手法で負圧側ピーク外圧係数 の統計值を算定したところ, 当該部位において-3.01 であった。こ れに対し, 4.4.1 同様に外圧係数の瞬間值で $95 \%$ に相当する -2.86 以 下の条件を課して条件付き平均場を求める。Fig. 26 は、Fig. 22 同様 に可視化した圧力等值面である。Fig. 22 と比較すると, 風圧係数-3.0 に相当する等值面はほとんど現れておらず，全体的に弱い負圧場と なっている。ただし，側面上端部を起点とする負圧分布形状より， 同様の円錐渦が形成されていることがわかる。したがって，本研究 対象のケース $\mathrm{A} ・ \mathrm{~B}$ と単独角柱ケースとは, 風向角は異なるものの, 同様の位置において円錐渦が形成され局所的にピーク負圧が強めら れる点で類似性が確認された。

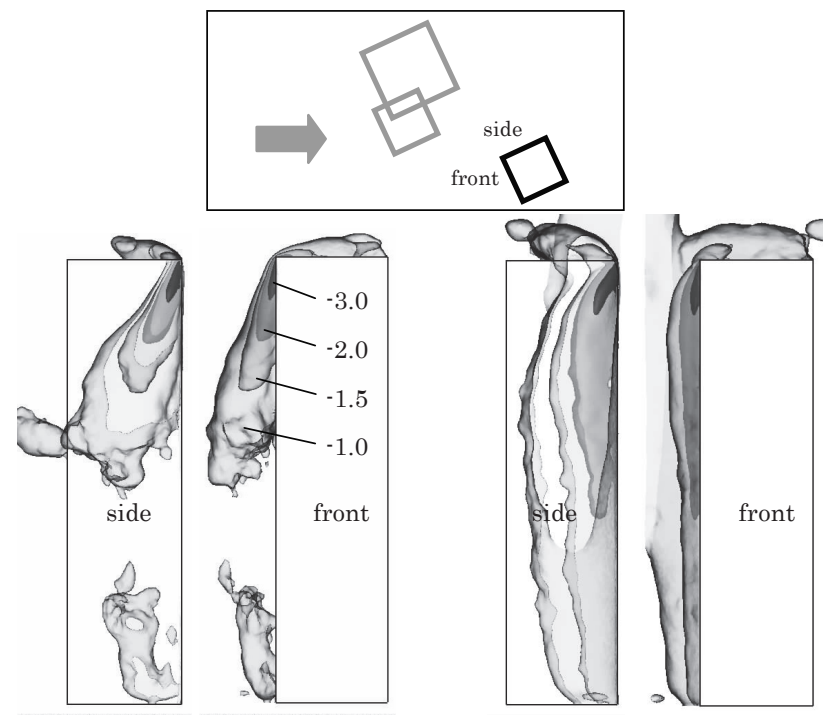

(1) case-A

(2) case-B

Fig.22 Iso surfaces of pressures

\section{4.3 渦度場に基づく考察}

前項より, 対象建物の側面上端部において発生するピーク負圧は, 単独角柱のグランシングアングル時と同様に円錐渦の形成によるも のであることが示された。しかしながら，ピーク負圧レベルが両者 で約 1.4 倍程度差があることから，風上建物の影響を受ける場合に はモデル特有の現象が介在しているものと思われる。

Fig. 27 は, 条件付き平均流れの計算結果に基づく渦度（鉛直軸成 分）の分布であり，ケース $\mathrm{A} ・ \mathrm{~B}$ それぞれについてピーク負圧発生 高さ $(0.975 H)$ に扮ける水平断面分布を示している。同様に Fig. 28 は単独角柱の結果であり，それぞれ同スケールで示している。

ケース $\mathrm{A} ・ \mathrm{~B}$ については, 風上建物からの剥離せん断層による渦 度場 (白: 正值) が対象建物隅角部に向かって伸びていると同時に, 対象建物隅角部から渦度場（黒：負值）が側面上を沿うよう分布し ている。Fig. 20（a）およびFig. 21 (a)において, 風上建物から剥離し 対象建物側面に沿う流れ場について示したが，その流れのプロセス において, 対象建物隅角部を起点として渦度の回転方向が逆転して いる様子が Fig. 27 から確認できる。Fig. 28 より, 単独角柱の場合 は接近流に明瞭な渦度分布はみられないが，側面を沿う洞度分布は Fig. 27 と同様に現れている。Fig. 29 は，対象建物の側面端部（円錐 渦の発生領域）におけるケース $\mathrm{A} ・ \mathrm{~B}$ ，および単独角柱の渦度分布 を示している。同図より, 当該領域においてケース $\mathrm{A} ・ \mathrm{~B}$ では単独 角柱の場合よりも渦度が強められていることがわかる。これは，各 ケースの対象建物隅角部に形成される円錐渦（渦度回転方向：負） に対する，風上建物からの剥離せん断層（渦度回転方向：正）の作 用に起因するものと考えられる。正の渦度場を形成する剥離せん断 層が対象建物隅角部を通過する際に, せん断層外縁部の局所的に増 加した流速成分が円錐渦の回転を促進させ，その循環が強められて いるものと考察される。これにより，ケース $\mathrm{A} ・ \mathrm{~B}$ では単独角柱に 比べて強い円錐渦が形成され，より大きいピーク負圧が発生してい

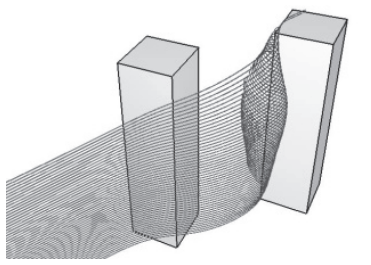

Fig.23 Time averaged flow lines

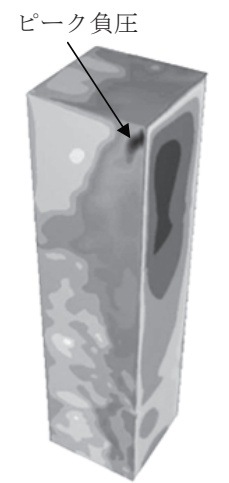

Fig. 25

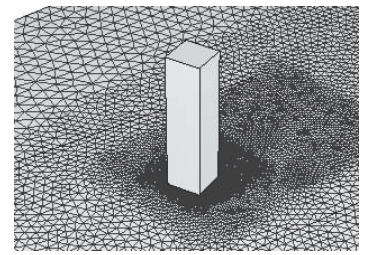

Fig.24 Computed model for Isolated square cylinder
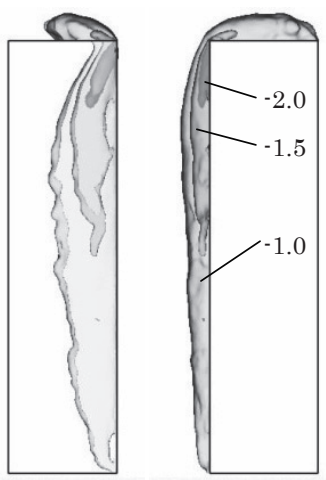

Fig.26 Iso surfaces of pressures for isolated square cylinder 


\section{るものと推測される。}

以上より, 風上側に同規模以上の建物が存在し, その位置関係と 風向に応じて剥離流れが角柱建物の隅角部に直接作用する場合 (Fig. 20 (a),Fig. 21 (a) ) には, グランシングアングルにおける単独 角柱と同様の円錐渦が形成されるだけでなく，風上からの剥離流れ がその円錐渦をさらに強め, 非常に大きいピーク負圧を発生させる 可能性があることが示された。
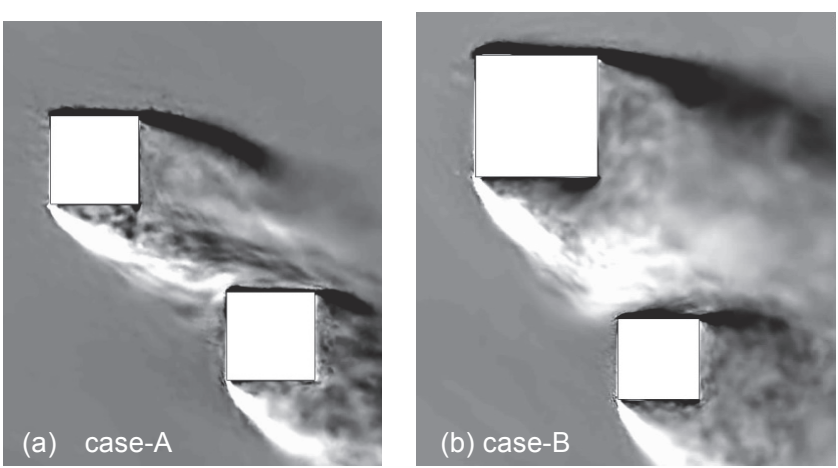

Fig.27 Horizontal distributions of vortisity

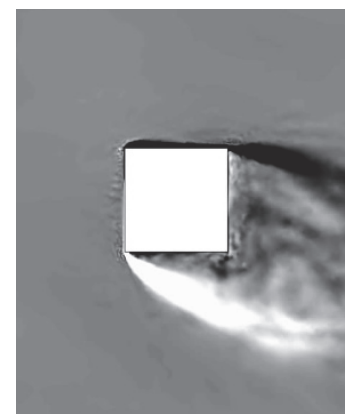

Fig.28 Horizontal distribution of vortisity for isolated square cylinder

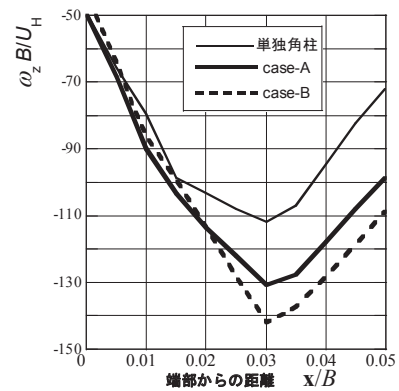

Fig.29 Vortisity distributions at the corner edge of leeward building

\section{5. 建物形状によるピーク負圧の低減効果}

\section{1 建物モデル}

角柱形状を有する高層建物において, 隅切, 隅欠, 隅丸といった 隅角部形状は，空力的対策のひとつとして一般に用いられており， 隅角部における剥離流れを制御することで抗力・揚力を低減できる ことが知られている。本研究におけるピーク負圧の増加現象に対し ても，隅角部の局所的な剥離・再付着流れを抑制することで上端部 の円錐渦を緩和できれば，風上建物の影響下においてもピーク負圧 の低減効果を見込むことができる。ここでは風下側の対象建物の隅 角部について $1 / 10 B$ の隅欠を施し，その効果を調べる。

隅欠を施した建物モデルをケースCとし, Fig. 30 に示す。風上建 物に関する寸法および位置関係はケース A と同様である。隅角部の 格子解像度については, 隅欠内の渦構造の再現が重要である。ここ では隅欠寸法を考慮した上で, 隅欠部を含む隅角部近傍においてケ 一ス A と同等の解像度（境界層要素も同様）とした。総要素数は約 934 万である。4 章に示した手法と同様の計算法および評価法に基 づき，本モデルで変動風圧評価を実施する。

\section{2 計算結果}

ケース Cの計算に基づく外圧係数分布について，ケース $\mathrm{A}$ と比較 しFig. 31 に示す。同図は, ケースAにおいて強いピーク負圧が発生 した測定高さ $(0.975 H)$ および中間高さ近傍 $(0.525 H)$ の水平断 面における平均外圧係数およびピーク外压係数（正側および負側） の分布を示している。ケース Aにおけるピーク負圧の発生位置近傍 $(0.975 H, x / B=4$ 付近）において, ケースCでは約 2.58 までピーク 負圧が低減されている。これは，隅角部のピーク外圧係数としては 単独角柱の值に近く，隅欠形状が有効であるといえる。

\section{3 建物周囲の流れ場}

ケースCにおいても, 前章同様にピーク外圧係数の $95 \%$ に相当す る条件付き平均場を求める (-2.45 以下)。高さ $0.975 H$ における建 物周囲の流れ場を Fig. 32 に示寸。風上建物からの剥離流れは，ケー ス A と同様に対象建物側面に沿うよう作用している。対象建物の隅 角部に着目すると，隅欠両端部（風上面端部から側面端部）におい て剥離・再付着による明瞭な渦構造がみられる。側面端部において 再剥離がみられるが, 剥離角度は浅く, ケース $\mathrm{A}$ ほど明瞭な渦構造 は現れていない。

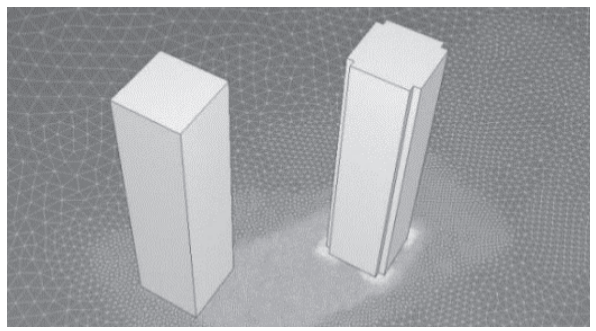

Fig.30 Computed model for building with slotted corners (case-C)

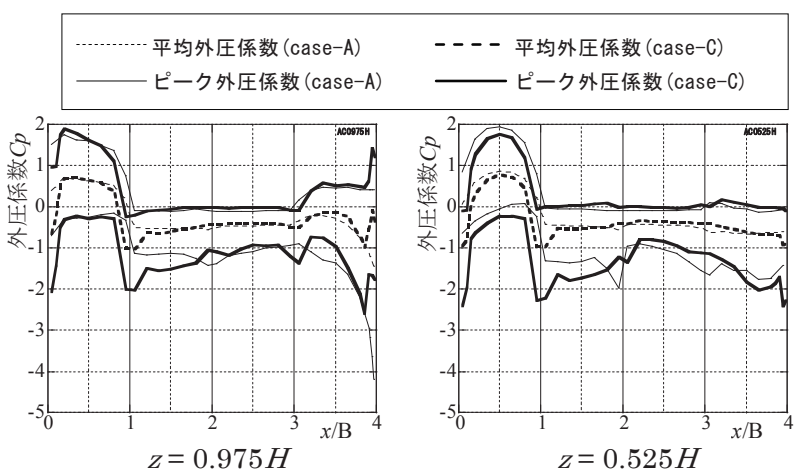

Fig.31 Horizontal distributions of pressure coefficients

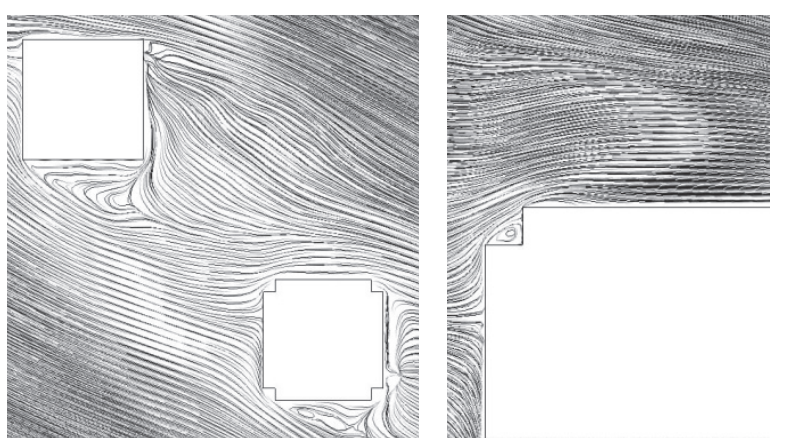

Fig.32 Conditional averaged flow field for case-C 
Fig. 33 に圧力等值面を示す。円錐渦の形成は、隅欠部に対して側 面端部側 (再剥離点) が起点となるよう移動しており, 圧力の大き さは単独角柱の場合（Fig. 26）と同程度であることがわかる。ただ し, 分布形状については, ケースCでも中央高さ付近において流れ の巻き込みが生じているために, ケース Aに類似したものとなって いる。

側面端部における渦度分布をFig. 34 に示す。ケースCでは側面端 部の剥離性状が変化していることからピーク位置が他ケースと若干 異なるが，その大きさは単独角柱の場合と同程度であり, ケース $\mathrm{A}$ よりも低減されていることが確認できる。

以上より, 隅角部が隅欠形状を有する場合, 局所的な渦形成の抑 制に効果があり，風上建物の影響下においてもピーク負圧が極端に 増加寸ることはなく，耐風設計上有効であると考えられる。
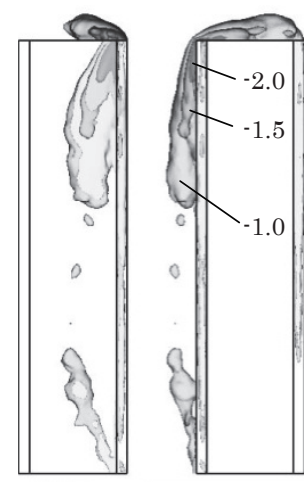
pressure coefficients
Fig.33 Iso surfaces of

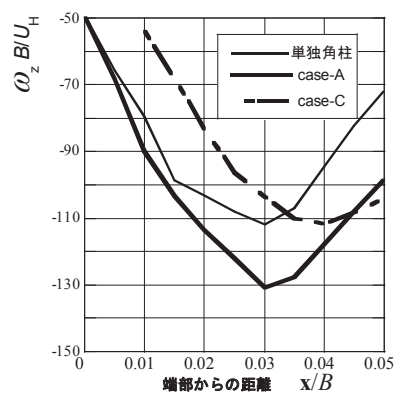

Fig.34 Vortisity distributions at the corner edge of leeward building

\section{6. 結論}

風上建物の影響を受け, 高層建物の局所負圧が増加する現象を対 象として非構造格子系 LES を行った。得られた知見を以下に示す。

（1）テトラ要素による非構造格子系は, 形状適合性だけでなく, 局 所的な渦の発生位置や剥離せん断層の可動範囲を考慮した上 で適切な格子解像度を合理的に計算モデルに反映させること ができるため, 非定常計算モデルの構築法として有効である。

（2）計算モデルを適切に構築するため, 特に建物間の空間における 格子解像度の影響について調べた。格子解像度は変動風速の高 周波数成分の再現性に影響をおよぼすため, 本研究対象のよう に周辺建物が直接影響する建物モデルの場合は, 対象建物周囲 のみ解像度を確保しても不十分であり, 周辺建物間で生じる流 れやその影響範囲を想定した上で格子解像度およびその空間 分布を決定する必要がある。

（3）顕著にピーク負圧が増加する事例（2 ケース）について LES の計算結果と風洞実験結果との比較を行った。計算結果に基づ く外压分布は, 実験值の分布性状を概ね再現できており, 本計 算法の妥当性が示された。

（4）条件付きサンプリングに基づく平均流れ場の計算結果に基づ いて，建物周囲の流孔場を調べたところ，ピーク負圧が発生す る建物上端部付近では, 風上建物から剥離したせん断層が対象
建物側面部を沿うように流れることがわかった。またその際, 対象建物隅角部においてきわめて局所的な渦構造が確認され た。

（5）負圧場に関する圧力等値面の空間分布より，対象建物側面にお いて上端部を起点とする円錐渦の形成が確認された。

（6）角柱上端部の円錐渦によるピーク負圧は，単独角柱モデル（グ ランシングアングル時）においてもその発生が確認された。た だし，風上建物の影響を受ける場合に比べてその負圧レベルは 小さい。

（7）対象建物上端部付近における渦度の分布性状を調べた。風上建 物からの剥離流れが対象建物隅角部に直接的に作用すること により隅角部の円錐渦の循環が強められ，当該部位においてよ り大きいピーク負圧が生じるものと推察される。

（8）風下側の対象建物に関し，隅欠によるピーク負圧の低減効果を 調べた。隅欠形状により渦形成の抑制が確認され，当該部位の ピーク負圧が単体角柱と同程度の值まで低減されることが確 認された。

（9）非構造格子系 LES は，周辺建物の影響を受けて局所風圧が増 加するような特殊な事象についても適用可能であり, その発生 メカニズムを調べる上でも有効である。

今後は, 耐風設計における LES の実用化に向け, より複雑な建 物形状モデルや実市街地モデル等を対象とした研究を進め, 計算精 度の検証とともに適切なモデル構築法を提案してゆく予定である。

\section{参考文献}

1) Bailey,P.A. and Kwok,K.C.S. : Interference excitation of twin tall buildings, J. Wind Eng. Ind. Aerodyn., Vol.21 , pp.323-338, 1985.12

2）谷池義人, 稲岡秀樹：連立する高層建物の境界層流中での相互作用, 第 9 回風工学シンポジウム, pp139-144, 1986.12

3）谷池義人：乱流境界層流中における直方体建物の相互作用，第 10 回 風工学シンポジウム, pp247-252, 1988.12

4）寺崎浩，中村良平：風上側の建物が高層建物の外装材用風荷重に与え る影響，第 21 回風工学シンポジウム , pp299-304, 2010.12

5）小野佳之，片岡浩人：LES の高層ビル群の風応答評価への適用－近接 する建物の取り扱い一, 日本建築学会大会学術講演梗概集，構造 I， pp197-198, 2010.09

6) Tamura,T. , Okuda,Y. , Kishida,T. , Nakamura,O. , Miyashita,K. Katsumura,A. and Tamari,M. : LES for aerodynamic characteristics of a tall building inside a dense city district , CWE2010, pp1-8, 2010,05

7) Tamura,T. and Nozu,T. : Introduction of unstructured-grid system on LES for wind pressure estimation on a building in cities , BBAA7, pp1-8, 2012.09

8）岸田岳士，田村哲郎，野津剛，勝村章，奥田泰雄，溜正俊：LES に よる建築物の風荷重評価の実用化検討，第 22 回風工学シンポジウム， pp293-298, 2012.12

9) Nozu,T. , Tamura,T. , Kishida,T. and Katsumura,A. : Mesh-adaptive LES for wind load estimation of tall building in a city , CWE2014, pp1-8, 2014.06

10）吉川優，田村哲郎：非構造格子系 LES による 3 次元角柱の変動風圧 評価，日本建築学会構造系論文集，第 78 巻，第 687 号，pp913-921， 2013.05

11）小野佳之，田村哲郎：三次元角柱側面に発生する局部負圧に関する LES，日本建築学会構造系論文集，第 78 巻，第 694 号， pp2065-2072, 2013.12 


\title{
LES OF FLUCTUATING WIND PRESSURES ON A HIGH-RISE BUILDING INFLUENCED BY WINDWARD BUILDING
}

- Formulation of LES using unstructured grid system for wind-resistant design of buildings (Part 2) -

\author{
Masaru YOSHIKAWA* and Tetsuro TAMURA** \\ * Senior Research Engineer, Technology Center, Taisei Corp., M. Eng. \\ ** Prof., Dept. of Environmental Science and Technology, Tokyo Institute of Technology, Dr. Eng.
}

Wind loads on high-rise buildings surrounded by other buildings in the real situation are quite different from those on isolated building. In order to evaluate the aerodynamic effect by adjacent building, some experimental results have been shown in previous papers. Terazaki and Nakamura ${ }^{4}$ carried out the wind tunnel experiments to obtain the wind pressures on a high-rise building influenced by windward building. As a result, the critical phenomena regarding the increase in the peak pressure were emphasized from a practical point of view.

On the other hand, recent development of techniques on computational fluid dynamics (CFD) has enabled us to simulate the complicated flow such as the wind around buildings. Large Eddy Simulation (LES) is expected to be adopted as an effective tool to evaluate wind load for wind-resistant design of buildings. For numerical prediction of wind pressures by LES for complicated models, unstructured grid systems are superior to conventional structured grid systems in terms of not only the adaptability to configuration but also flexibility to mesh density at each location in the computational region. Present authors previously discussed the applicability of unstructured LES using tetrahedral cells for prediction of the fluctuating wind pressures on a three-dimensional square cylinder by comparison with experiments. In this study, the availability of unstructured LES to evaluate the peak pressures on a high-rise building influenced by windward building is examined focusing on the phenomena that the negative peak pressure extremely intensifies at the corner edge of the leeward building.

First, the formulation method of the computed model is studied for accurate prediction. Focusing on the region between building models, the influence of the unstructured grid resolution is examined regarding the fluctuating velocities and pressures. As the turbulence structure of unsteady flow is affected by the spatial resolution, sufficient mesh density is required around the building models.

The computed results of the pressures on the leeward building are validated by comparison with the experiments for two specific cases that the negative peak pressure intensifies at the corner edge of the building. The computed pressure distributions qualitatively coincide with experiments and the peak values are reproduced with good accuracy.

In order to clarify the mechanism of pressure intensification, the conditional averaged flow fields are visualized. The separated shear layer from the windward building flows along the side surface of the leeward building and the separation vortex is formed locally close to the corner edge region where the negative peak pressure occurs. Based on the visualization of negative pressure contours, the conical vortex is observed at the corner edge of the leeward building as is the case in the isolated building model under the condition of glancing angle. Moreover, the vortisity distributions are examined for the flow fields around building models. The pressure intensification at the corner edge of leeward building is thought to be due to the vortisity intensification by the effect of reverse vortisity in the separated shear layer from the windward building.

Finally, the effect of the building configuration to reduce the peak pressure is examined. The slotted corners are employed for the leeward building model and the fluctuating pressures are recomputed using unstructured LES. The vortex formation is suppressed at the corner edge and the reduction effect of peak pressure is confirmed.

As a conclusion of this study, unstructured LES is available to evaluate the wind loads on buildings influenced by adjacent buildings and effective to elucidate the flow mechanism for various aerodynamic phenomena. 